\title{
Responses of Vitis vinifera 'Pinot gris' Grapevines to Exogenous Abscisic Acid (ABA): I. Yield, Fruit Quality, Dormancy, and Freezing Tolerance
}

\author{
Shouxin $\mathrm{Li}^{1} \cdot$ Imed E. Dami ${ }^{1}$
}

Received: 6 February 2015 / Accepted: 3 June 2015/Published online: 4 August 2015

(c) The Author(s) 2015. This article is published with open access at Springerlink.com

\begin{abstract}
Economic losses due to cold weather events are a major constraint to the expansion of premium but coldsensitive winegrape cultivars in colder regions, such as Ohio (USDA) Plant Hardiness Zones 6b-5b ( -17.8 to $-26.1{ }^{\circ} \mathrm{C}$ ) (ARS-USDA 2012). The purpose of this study was to determine whether a foliar application of abscisic acid (ABA) could increase the freezing tolerance (FT) of field-grown 'Pinot gris' grapevines (Vitis vinifera), and whether the effectiveness of ABA treatments can be influenced by the phenological timing of the application. Mature 'Pinot gris' grapevines were treated with a foliar application of $\mathrm{ABA}$ at a concentration of $0 \mathrm{mg} \mathrm{L}^{-1}$ (control), or $400 \mathrm{mg} \mathrm{L}^{-1}$ at vine phenological stages corresponding to véraison, post-véraison, and postharvest. $\mathrm{ABA}$ application did not affect yield components, fruit composition, or vegetative growth, but caused early leaf senescence, leaf abscission, and advanced dormancy that led to increased FT of 'Pinot gris' during the dormant season. The phenological timing of application influenced ABA effectiveness, with spray applications made at véraison and post-véraison being the most effective. It was concluded that a foliar application of ABA increased bud FT during the dormant season, and thus, $\mathrm{ABA}$ is a potential cultural practice tool for mitigating economic losses from cold injury in production regions with damaging cold events.
\end{abstract}

Keywords Freezing tolerance - Dormancy - Thermal analysis $\cdot$ Low-temperature exotherm $\cdot$ Cold injury

Imed E. Dami

dami.1@osu.edu

1 Department of Horticulture and Crop Science, Ohio Agricultural Research and Development Center, The Ohio State University, Wooster, OH 44691, USA

\section{Introduction}

Grape production regions in the northern U.S. have experienced substantial economic losses in production due to cold weather events in 2003, 2004, 2005, 2009, 2012, and 2014 (Zabadal and others 2007; Dami and others 2012, 2014). The state of Ohio has experienced consecutive freezing-related losses of grape production over the past 5 years, with the greatest loss in 2014 (Dami and others 2014; Dami and Lewis 2014). The recent weather events are of great concern as they threaten the expansion of Vitis vinifera acreage and production and thus their economic sustainability not only in Ohio (USDA Plant Hardiness Zones $6 \mathrm{~b}-5 \mathrm{~b}$ ( -17.8 to $-26.1{ }^{\circ} \mathrm{C}$ ) (ARS-USDA 2012) but also in other regions that experience winter sub-freezing events. To mitigate the threat of cold damage in grapes, various protection methods have been developed, with the purpose of either changing the environmental conditions in the vineyard or improving the FT of grapevines. Active methods involve protection immediately prior to or during the freeze event and include the use of wind machines, heaters, and over-vine water sprinklers (Poling 2008). Preventative methods involve protection long prior to a freeze event such as site and variety selection (Zabadal and others 2007) and the application of chemical protectants (Dami and Beam 2004). Among the chemical protectants, foliar applications of the plant growth regulator ABA have been found to increase FT in various plant species including Arabidopsis (Mantyla and others 1995), silver birch (Li and others 2003), barley (Bravo and others 1998), rye (Churchill and others 1998), wheat (Dallaire and others 1994), chickpea (Kumar and others 2008), potato (MoraHerrera and Lopez-Delgaelo 2007), sugar maple (Bertrand and others 1997), and apple (Guak and Fuchigami 2001). Previous work by Dami's group has demonstrated that 
ABA also increased FT of grape species (Zhang and Dami 2012a, 2012b; Dami and others 2015). The cultivar, Vitis vinifera, 'Pinot gris', is cold sensitive and widely planted in production regions where winter weather events commonly cause cold injury (Zabadal and others 2007). However, it is not known whether ABA would improve the FT of this economically important cultivar. Therefore, the purpose of this study was to investigate whether a foliar application of $\mathrm{ABA}$ and the phenological timing of this application would enhance the FT of 'Pinot gris' without adversely affecting its reproductive or vegetative growth.

\section{Materials and Methods}

\section{Plant Material and Treatments}

The field study was conducted at the Ashtabula Agricultural Research Station (AARS), in Kingsville in northeast Ohio (USDA Plant Hardiness Zone 6b $(-17.8$ to $-20.6{ }^{\circ} \mathrm{C}$ ) (ARS-USDA 2012). 'Pinot gris' grapevines (Clone 146, rootstock 101-14) were planted in 1995 at AARS and vines were spaced $1.5 \times 2.4 \mathrm{~m}^{2}$ (vine $\times$ row). Grapevines were trained to a bilateral low cordon training system with vertically shoot positioned (VSP), and spur pruned to 15 buds per meter of cordon. Treatments were applied on vines using a randomized complete block with four blocks and four treatments each consisting of 4-vine plots bordered by untreated buffer vines $(2-4)$. The four treatments consisted of the following: (1) control (no $\mathrm{ABA})$, (2) ABA applied at $50 \%$ véraison (50\% berry softening and color change), (3) ABA applied at postvéraison (2-3 weeks after $50 \%$ véraison), and (4) $A B A$ applied at postharvest (6-8 weeks after $50 \%$ véraison). $\mathrm{ABA}$ and control (no ABA) foliar spray solutions were prepared using deionized water and the spreader-sticker Latron B-1956 ${ }^{\circledR}$ (Dow AgroScience, Midland, MI) at $0.05 \%$ (v/v). The ABA solutions containing $400 \mathrm{mg} \mathrm{L}^{-1}$ were prepared using Protone ${ }^{\circledR}$ SG (Valent BioSciences Corporation, Libertyville, IL) which contains $20.0 \%$ (w/ asDERw) s-ABA as the active ingredient. The sprays were applied to both sides of the vine canopy (leaves and clusters) using a backpack sprayer that averaged a spray volume of $0.5 \mathrm{~L}$ per vine. The experiments were repeated for two growing seasons (2012 and 2013).

\section{Leaf Senescence and Abscission}

In 2012, leaf senescence was visually observed, and photos were taken of all treatments. Leaf abscission was determined by counting leaves per shoot pre- and post-ABA application and computing leaf abscission percentage. In 2013, leaf senescence was monitored by measuring chlorophyll content using SPAD-520 chlorophyll meter (Spectrum Technologies, Inc. East-Plainfield, IL). Four shoots (one shoot per vine) were randomly tagged per treatment-replicate, and chlorophyll measurements were recorded bi-weekly on the upper surface of the basal four leaves (node position 4, 5, 6, 7). Leaf abscission was also recorded at the same time and on the same shoots as described above.

\section{Yield, Fruit Quality, and Vegetative Growth}

Yield components consisted of collecting crop weight per vine, cluster number per vine, and computing cluster weight (crop weight/cluster number). A 100-berry sample from each treatment-replicate was collected at harvest and weighed using an electronic scale (Denver Instrument, Bohemia, NY), and the berry number per cluster was calculated [(cluster weight/100-berry weight $\times 100$ ]. The 100-berry sample was crushed on the day of sampling to assess fruit composition by measuring three basic parameters: soluble solids (SS), $\mathrm{pH}$, and titratable acidity (TA). The released juice was pressed through cheesecloth and used to measure SS (\%) with a digital refractometer (MISCO, Cleveland, $\mathrm{OH}$ ), $\mathrm{pH}$ with a $\mathrm{pH}$ electrode (London Scientific, London, Canada), and TA by titrating $5 \mathrm{~mL}$ of juice with $0.1 \mathrm{~N}$ sodium hydroxide $(\mathrm{NaOH})$ to a $\mathrm{pH}$ endpoint of 8.2 using an automatic titrator $(\mathrm{PH} / \mathrm{EP}$ Titration Workstation Model 350/352) with SAC80 Sample change (Denver Instrument, Bohemia, NY). The annual vegetative growth was estimated from the weight of one-year-old canes/vine, and determined from vines left unpruned (not sampled for freezing tests) in each treatment-replicate. The Ravaz index, also referred to as crop load, was calculated as the ratio of crop weight to pruning weight per vine (Ravaz 1903).

\section{Bud Dormancy}

Bud samples were collected monthly from 31Aug 2012 to 21 Mar 2013 in the first year of study and from 6 Sept 2013 to 21 Nov 2013 in the second year of study. All dormancy assays were conducted on the same day of sample collection and followed the method reported by Zhang and others (2011). Eighteen single-node cuttings were prepared from a total of 24 buds on three eight-node canes. Canes with visible periderm formation were excised into one-node cuttings about $5-\mathrm{cm}$ long, then inserted into $2.5 \times 2.5 \mathrm{~cm}^{2}$ foam medium (Smithers-Oasis, Kent, $\mathrm{OH}$ ) and placed in $55 \times 25 \times 7 \mathrm{~cm}^{3}$ plastic trays (T.O. Plastics, Clearwater, $\mathrm{MN}$ ) filled with deionized water. Trays were then placed under forcing conditions in a growth chamber (Conviron ${ }^{\circledR}$, Pembina, ND) with the following settings: 12-h photoperiod with $300 \mu \mathrm{mol} \mathrm{m} \mathrm{m}^{-2} \mathrm{~s}^{-1}, 22{ }^{\circ} \mathrm{C}$, and $50 \%$ relative 
humidity (Zhang and Dami 2012a). Budburst was recorded as Eichhorn-Lorenz (EL) stage 5 (Eichhorn and Lorenz 1977) and monitored three times per week for 30 days. Dormancy was estimated as the number of days to $50 \%$ budburst (D50BB), with higher values of D50BB indicating more dormant buds (Wake and Fennell 2000).

\section{Freezing Tolerance}

One-year-old canes with seven basal buds (node positions three to nine) were collected from each treatment-replicate. The canes were wrapped in plastic bags and placed in a cooler with ice packs and shipped overnight to the laboratory in Wooster. Canes were stored in a refrigerator at $4{ }^{\circ} \mathrm{C}$, and freezing tests were conducted within $48 \mathrm{~h}$ from time of collection. FT was determined by thermal analysis described briefly as follows. Buds were excised and placed on thermoelectric modules (MELCOR, Trenton, NJ), which were placed in a temperature-controlled chamber (Tenney ${ }^{\circledR}$; Thermal Products Solutions, New Columbia, PA). The chamber temperature was held at $-2{ }^{\circ} \mathrm{C}$ for $30 \mathrm{~min}$ and then lowered to $-50{ }^{\circ} \mathrm{C}$ at the rate of $4{ }^{\circ} \mathrm{C} \mathrm{h}^{-1}$. The FT of buds was determined by identifying the median or mean low-temperature exotherm (MLTE), which corresponds to the lethal temperature that kills $50 \%$ of the population, or $\mathrm{LT}_{50}$ (Wolf and Pool 1987). Canes for freezing tests were collected at the same times as those used to determine bud dormancy from 31 Aug 2012 to 21 Mar 2013 in the first year of study and from 6 Sept 2013 to 21 Nov 2013 in the second year of study.

On 7 Jan 2014, the vineyard site experienced subfreezing events with a minimum low temperature of $-25.3{ }^{\circ} \mathrm{C}$. This temperature was lower than the $\mathrm{LT}_{50}$ of 'Pinot gris' $\left(-21.3{ }^{\circ} \mathrm{C}\right)$ measured on 25 Nov 2013. As a result, canes were collected to assess the extent of cold damage. On 13 Jan 2014, ten canes with ten buds (node position one to ten) per cane were collected from each treatment-replication combination and stored for $24 \mathrm{~h}$ at room temperature. Buds were excised using razor blades to visually assess the viability of primary, secondary, and tertiary buds as well as cane phloem tissue and categorized as dead or alive based upon the presence or absence of brown tissue (Dami and others 2012). Winter injury was expressed as a percentage by dividing the number of damaged buds or canes with dead tissue by the sample size and multiplying by 100 .

\section{Field Budburst}

After pruning in 2013, the total number of buds per vine was counted and recorded. Budburst was quantified by recording the percent of buds per vine at the EL (Eichhorn and Lorenz 1977) stage 5 and monitored three times per week until $80 \%$ or more of buds burst. Budburst was not evaluated in 2014 because of winterkill.

\section{Weather Data and Statistical Analysis}

Daily minimum and maximum temperatures were collected and recorded by the weather station located at the AARS research vineyard in Kingsville (OARDC Weather Station System 2014). Cumulative growing-degree days (GDD), which indicate the growing season heat, were computed as cumulative daily mean temperatures with base $10^{\circ} \mathrm{C}$ from 1 Apr. to 31 Oct. The dates of first fall frost events, which correspond to the date of the first occurrence of temperature below $0{ }^{\circ} \mathrm{C}$ in the fall, were also recorded. Frost-free days (FFD), which indicate the growing season duration, were computed as the successive number of days with a minimum daily temperature at or above $0{ }^{\circ} \mathrm{C}$. Days after budburst (DAB) indicate the number of days from budburst to the corresponding vine phenological stage (Table 1). All data were subjected to analysis of variance using SAS statistical software (version 9.3; SAS Institute, Cary, NC). When treatments were statistically different, an LSD test was used for mean comparison $(P \leq 0.05)$.

\section{Results}

\section{ABA Application Dates and Corresponding Weather and Phenology}

In both years, ABA applications at véraison, post-véraison, and postharvest corresponded to the following GDD ranges: 943-1138, 1292-1296, and 1307-1493, respectively (Table 1). ABA applications at the three phenological stages also corresponded to the following DAB ranges 105-107, 120-134, and 148-158, respectively. In year 1, grapes were harvested on 19 Sept 2012, and the cumulative GDD was 1637 with 191 FFD. In year 2, grapes were harvested on 24 Sept 2013, and the cumulative GDD was 1438 with 199 FFD (Table 1).

\section{Leaf Senescence and Abscission}

In early October of 2012, ABA-treated 'Pinot gris' grapevines showed color change of leaves earlier than the untreated (control) vines with increased intensity of yellowing from véraison to postharvest treatment (Fig. 1a). During the same period of time, no differences of leaf abscission were observed among treatments $(\sim 20 \%)$ except for postharvest treatment $(\sim 80 \%)$, which exhibited the earliest defoliation (Figs. 1b, 2a). In 2013, leaf senescence was monitored based on chlorophyll content, which was steady in September then declined in October in both 
Table 1 Abscisic acid (ABA) application dates (at véraison, post-véraison, and postharvest) and harvest dates and corresponding growing degree days (GDD) and days after budburst (DAB) relative to the phenology of 'Pinot gris'

\begin{tabular}{|c|c|c|c|c|c|c|c|c|c|c|c|c|c|}
\hline \multicolumn{3}{|l|}{ Véraison } & \multicolumn{3}{|c|}{ Post-véraison } & \multicolumn{3}{|l|}{ Harvest } & \multicolumn{3}{|c|}{ Postharvest } & \multirow[t]{2}{*}{$\mathrm{GDD}^{\mathrm{c}}$} & \multirow[t]{2}{*}{$\mathrm{FFD}^{\mathrm{d}}$} \\
\hline Date & $\mathrm{GDD}^{\mathrm{a}}$ & $\mathrm{DAB}^{\mathrm{b}}$ & Date & GDD & $\mathrm{DAB}$ & Date & GDD & DAB & Date & GDD & $\mathrm{DAB}$ & & \\
\hline \multicolumn{14}{|c|}{ Year 1 (2012) } \\
\hline 16 Aug. & 1138 & 105 & 31Aug & 1296 & 120 & 19 Sept & 1464 & 139 & $28 \mathrm{Sept}$ & 1493 & 148 & 1637 & 191 \\
\hline \multicolumn{14}{|c|}{ Year 2 (2013) } \\
\hline 21Aug & 943 & 107 & 17 Sept & 1292 & 134 & 24 Sept & 1225 & 141 & $11 \mathrm{Oct}$ & 1307 & 158 & 1438 & 199 \\
\hline
\end{tabular}

${ }^{a} G D D$ cumulative daily mean temperatures with base $10^{\circ} \mathrm{C}$ from 1 Apr. through date of corresponding stage of development

b $D A B$ days after budburst

c $G D D$ cumulative daily mean temperatures with base $10{ }^{\circ} \mathrm{C}$ from 1 Apr. through 31 Oct

d $F F D$ successive days with minimum daily temperatures at or above $0{ }^{\circ} \mathrm{C}$

Fig. 1 Effect of abscisic acid (ABA) on leaf senescence and abscission of 'Pinot gris' grapevines grown in Kingsville, OH. Photos were taken on a 09 Oct 2012 and b 17 Oct 2012. Grapevines were sprayed with $0 \mathrm{mg} \mathrm{L}^{-1}$ (control) and $400 \mathrm{mg} \mathrm{L}^{-1} \mathrm{ABA}$ at $50 \%$ véraison on 16 Aug 2012, postvéraison on 31 Aug 2012, and postharvest on 28 Sept 2012. Note: increased yellowing of leaves as ABA was applied later in the season from veraison to postharvest, which had the most abscised leaves
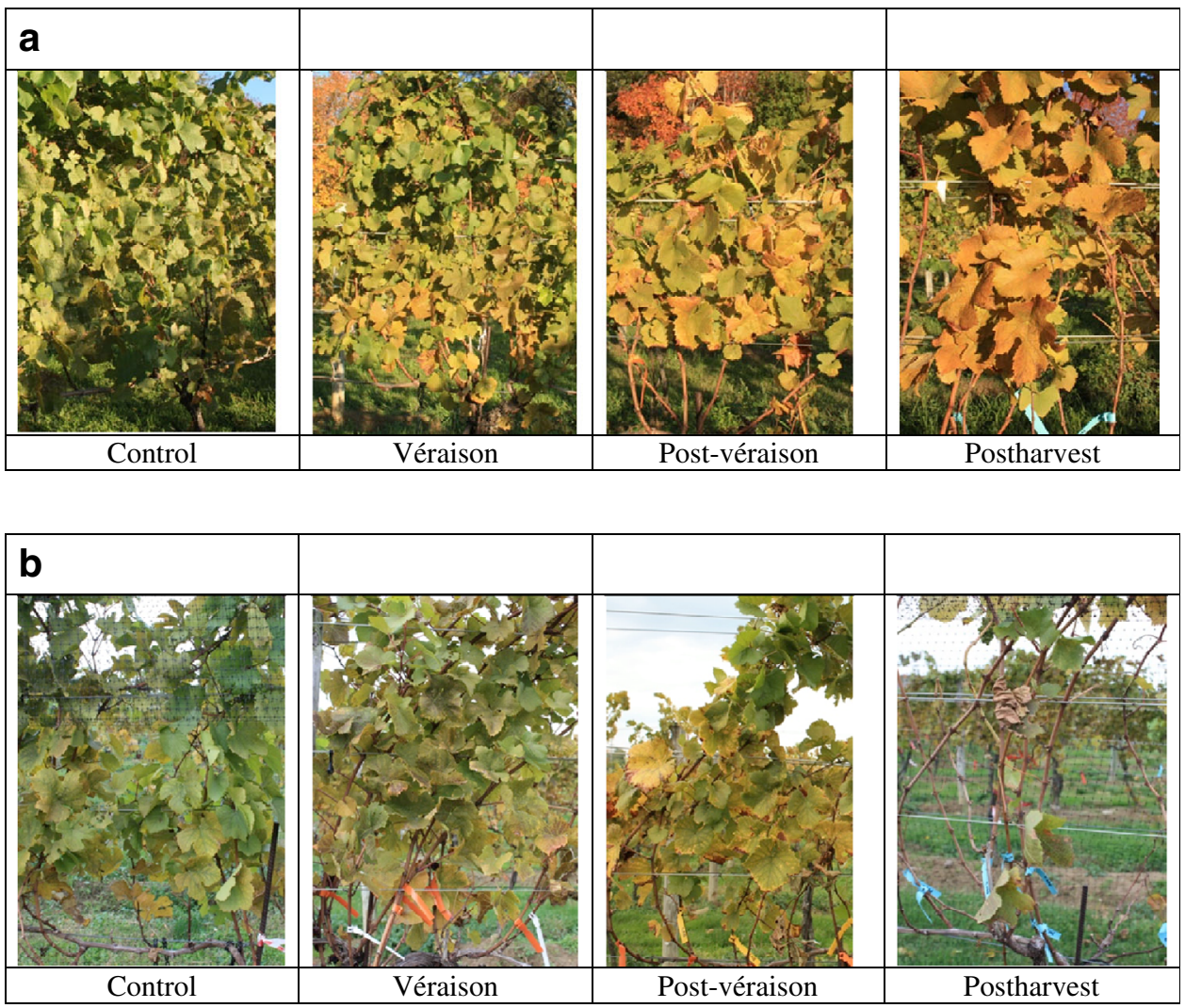

control and ABA-treated leaves. There were no treatment differences on all dates except on 11 Oct (Fig. 3). ABA caused early and increased leaf abscission and resulted in nearly complete defoliation in post-véraison-treated vines by harvest time (Fig. 2b). Similar to year 1, postharvest ABA caused complete abscission 10 days after application, while control vines had $40 \%$ defoliation (Fig. 2b).

\section{Yield, Fruit Quality, and Vegetative Growth}

In both years, $\mathrm{ABA}$ did not affect yield components or the basic fruit chemical composition of 'Pinot gris'. During the 2-year study, the mean ranges of yield components and fruit compositions at harvest were $2.62-3.19 \mathrm{~kg} / \mathrm{vine}$ yield, 24-33 clusters/vine, 91-122 g cluster weight, 55-80 
Fig. 2 Effect of abscisic acid (ABA) on leaf abscission of 'Pinot gris' grapevines grown in Kingsville in a 2012 and b 2013. In 2012, Control, véraison, post-véraison, and postharvest treatments corresponded to ABA application on 16 Aug 2012, 31 Aug 2012, and 28 Sept 2012, respectively. In 2013, Control, véraison, post-véraison, and postharvest treatments corresponded to $\mathrm{ABA}$ application on 21 Aug 2013, 17 Sept 2013, and 11 Oct 2013, respectively. Different letters indicate statistical significance at $p \leq 0.05$
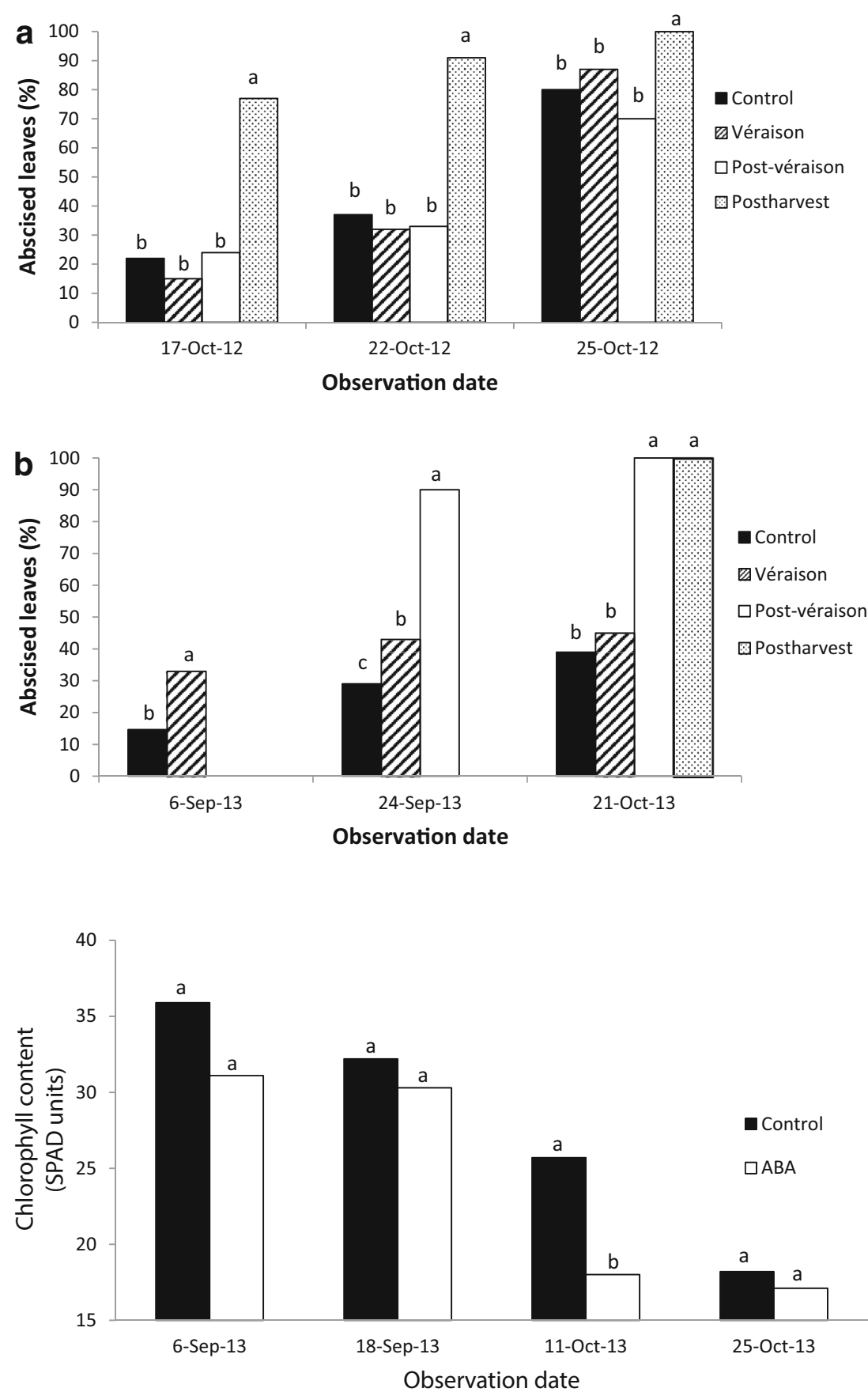

Observation date
Fig. 3 Effect of abscisic acid (ABA) on chlorophyll content of 'Pinot gris' grapevines grown in Kingsville in 2013. For clarity, only one ABA plot was presented which was the average of véraison (ABA sprayed on 21 Aug 2013), postvéraison (ABA sprayed on 17 Sept 2013), and postharvest (ABA sprayed on 11 Oct 2013). Different letters indicate statistical significance at $p \leq 0.05$ berries/cluster, $1.47-1.66 \mathrm{~g}$ berry weight, $19.4-23.5^{\circ} \mathrm{Brix}$ SS, 3.39-3.59 pH, and 5.9-6.6 $\mathrm{g} \mathrm{L}^{-1}$ TA (Table 2). The pruning weight, an indicator of vegetative growth, also showed no response to $\mathrm{ABA}$ treatment and ranged between 0.5 and $0.65 \mathrm{~kg} /$ vine (Table 2). The Ravaz index, an indicator of balance between reproductive and vegetative growth, ranged between 4.2 and 6.4 during the 2 -year study and was not different among treatments (Table 2). Furthermore, the Ravaz index among all treatments was within the optimum range of 5-10 suggesting that vines were balanced (Smart and Robinson 1991).

\section{Bud Dormancy}

In both years, D50BB ranged from 15 to 45 indicating that vines transitioned from non-dormant to dormant state, respectively. Under forcing conditions, the pattern of budburst was similar in both years and among treatments. 
Table 2 Effect of abscisic acid (ABA) on yield components, fruit composition, and vine size in 'Pinot gris' grapevines grown in Kingsville, Ohio

\begin{tabular}{|c|c|c|c|c|c|c|c|c|c|c|}
\hline Treatment $^{\mathrm{a}}$ & $\begin{array}{l}\text { Yield/vine } \\
(\mathrm{kg})\end{array}$ & $\begin{array}{l}\text { Clusters/ } \\
\text { vine }\end{array}$ & $\begin{array}{l}\text { Cluster } \\
\text { wt (g) }\end{array}$ & Berries/cluster & $\begin{array}{l}\text { Berry wt } \\
\text { (g) }\end{array}$ & $\begin{array}{l}\text { Pruning wt/ } \\
\text { vine }(\mathrm{kg})\end{array}$ & $\begin{array}{l}\text { Ravaz } \\
\text { index }\end{array}$ & $\begin{array}{l}\text { SS } \\
\left({ }^{\circ} \text { Brix }\right)\end{array}$ & $\mathrm{pH}$ & $\begin{array}{l}\text { Titratable acidity } \\
\left(\mathrm{g} \mathrm{L}^{-1}\right)\end{array}$ \\
\hline & \multicolumn{10}{|c|}{ Harvest: 19 Sept 2012} \\
\hline $\begin{array}{l}\text { Control (no } \\
\text { ABA) }\end{array}$ & 3.11 & 31 & 100 & 63 & 1.60 & 0.53 & 5.9 & 23.4 & 3.53 & 6.5 \\
\hline Véraison & 2.70 & 30 & 91 & 55 & 1.66 & 0.65 & 4.2 & 23.5 & 3.54 & 6.5 \\
\hline $\begin{array}{l}\text { Post- } \\
\text { véraison }\end{array}$ & 3.13 & 33 & 95 & 61 & 1.55 & 0.62 & 5.1 & 23.2 & 3.59 & 6.5 \\
\hline Postharvest & 2.91 & 31 & 95 & 58 & 1.64 & 0.58 & 5.0 & 23.5 & 3.50 & 6.6 \\
\hline \multirow[t]{2}{*}{ Significance $^{\mathrm{d}}$} & NS & NS & NS & NS & NS & NS & NS & NS & NS & NS \\
\hline & \multicolumn{10}{|c|}{ Harvest: 24 Sept 2013} \\
\hline $\begin{array}{l}\text { Control (no } \\
\text { ABA) }\end{array}$ & 2.94 & 26 & 113 & 72 & 1.58 & 0.59 & 5.0 & 19.8 & 3.39 & 6.5 \\
\hline Véraison & 3.17 & 26 & 122 & 80 & 1.53 & 0.64 & 5.0 & 19.6 & 3.50 & 6.4 \\
\hline $\begin{array}{l}\text { Post- } \\
\text { véraison }\end{array}$ & 3.19 & 27 & 118 & 75 & 1.57 & 0.50 & 6.4 & 19.7 & 3.51 & 5.9 \\
\hline Postharvest & 2.62 & 24 & 109 & 74 & 1.47 & 0.50 & 5.2 & 19.4 & 3.43 & 6.3 \\
\hline Significance & NS & NS & NS & NS & NS & NS & NS & NS & NS & NS \\
\hline
\end{tabular}

SS Soluble solid, NS Not significant

${ }^{a}$ Véraison, post-véraison, postharvest: ABA sprayed at $50 \%$ véraison, 20 and 50 days after $50 \%$ véraison, respectively

${ }^{\mathrm{b}}$ Ravaz index was calculated by dividing total yield per vine by the pruning weight recorded during the winter following each season

Values of D50BB of single-node cuttings started low in late summer and then increased steadily toward the autumn season reaching maximum values in mid-(year 2012) to late-(year 2013) October, indicating that 'Pinot gris' entered the deepest dormancy state (Fig. 4). Values of D50BB typically decreased rapidly after peaking in October (17 Oct in 2012 and 30 Oct in 2013) and reached lowest values on 21 March 2013 (Fig. 4a, b). Even though the dormancy pattern was the same among all treatments, ABA-treated vines had a delayed budburst compared to control, and the magnitude of the delay varied with treatment and season. In the first study year, post-véraison application showed the most significant delay of budburst under forcing conditions, and averaged 6 days from midOctober to early January (Fig. 4a). In the second study year, véraison application caused the most budburst delay averaging 7 days from early September to late November. The delay of budburst is indicative that ABA-treated vines entered a deeper dormancy than the untreated vines. In both years, the later ABA application during postharvest did not affect bud dormancy (data not shown).

\section{Freezing Tolerance}

During the 2012-2013 dormant season, the first fall frost occurred on 12 Oct 2012, and the lowest temperature $\left(-16.3{ }^{\circ} \mathrm{C}\right)$ occurred on $18 \mathrm{Feb} 2013$ (Fig. 5a). Throughout the dormant season, the minimum air temperatures were higher than the lowest $\mathrm{LT}_{50}$ indicating that the critical temperatures to cause tissue damage were not reached. Exogenous ABA increased bud FT of 'Pinot gris' throughout the dormant season particularly during the cold acclimation and deacclimation stages (Fig. 6a). Véraison and post-véraison applications were the most effective and increased FT by an average of $2.3{ }^{\circ} \mathrm{C}$ during the autumn acclimation (late August-mid-December) and $2{ }^{\circ} \mathrm{C}$ during the late winter deacclimation (late February-late March) (Fig. 6a). During the 2013-2014 season, the first fall frost occurred on 29 Nov 2013 (Fig. 5b). During the period between January and March, minimum temperatures below $-20{ }^{\circ} \mathrm{C}$ occurred nine times and ranged from -21.0 to $-25.9^{\circ} \mathrm{C}$. These temperatures were colder than midwinter $\mathrm{LT}_{50}$, indicating that the critical temperatures to cause tissue damage were reached. Therefore, freezing tests were only conducted from 6 Sept. to 25 Nov 2013 and were interrupted after the lethal freezing events. Bud samples were collected after these sub-freezing events to determine tissue damage. In the second study year, ABA applications at véraison and post-véraison were again the most effective and increased the FT of 'Pinot gris' by an average of $2.2{ }^{\circ} \mathrm{C}$ during the autumn acclimation (early September to late November). Following the successive temperature events below $-20^{\circ} \mathrm{C}$, primary, secondary, and tertiary buds sustained $100 \%$ damage. However, phloem cane 
Fig. 4 Effect of abscisic acid (ABA) on bud dormancy (days to $50 \%$ budburst) on 'Pinot gris' grown in Kingsville during a 2012-2013 and b 2013-2014 seasons. For clarity, only control and ABA treatments with significant effect are presented. In 2012, ABA (postvéraison) was sprayed on 31 Aug 2012. In 2013, ABA (véraison) was sprayed on 21 Aug 2013. Different letters indicate statistical significance at $p \leq 0.05$
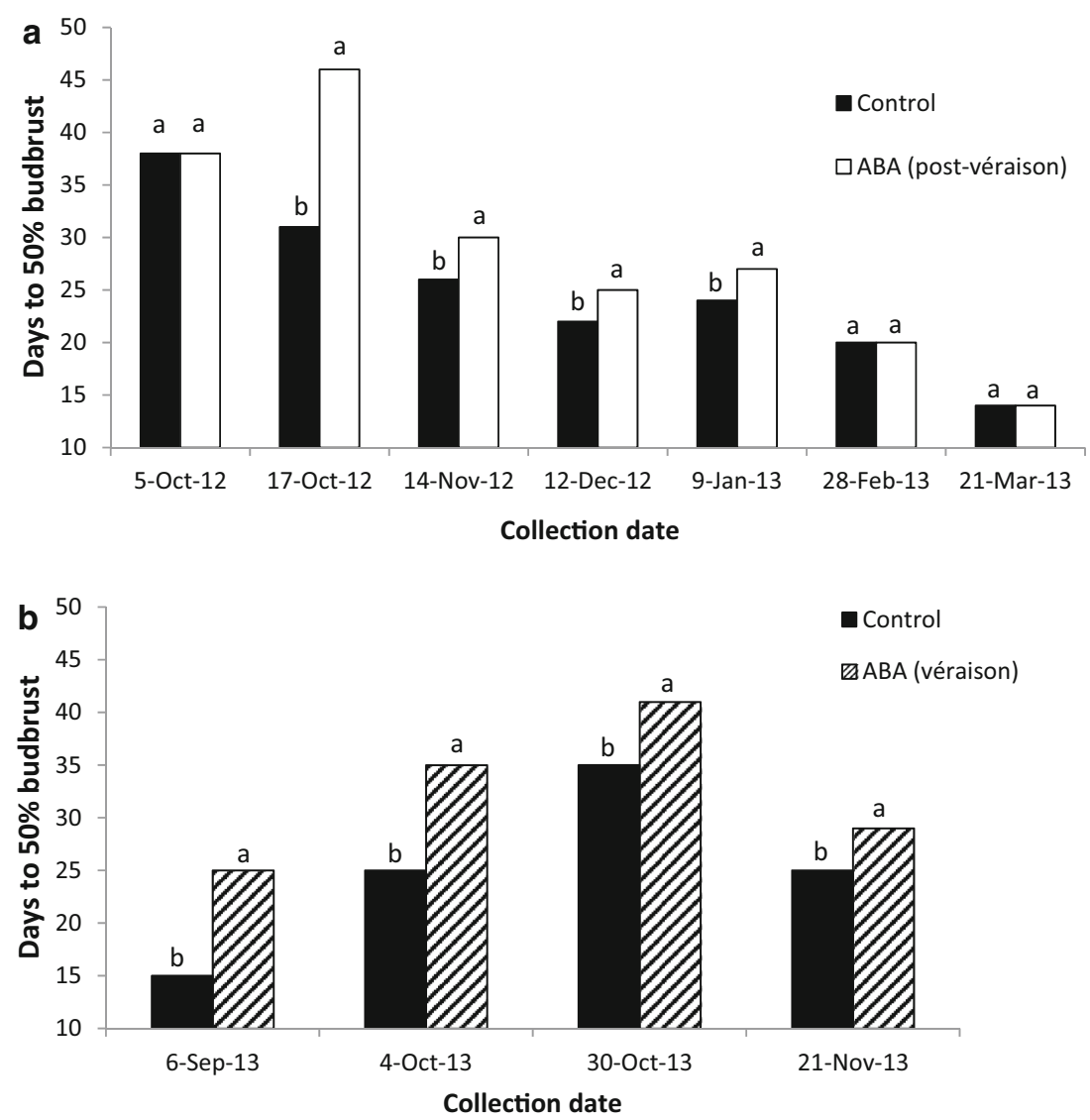

injury was highest in control $(30 \%)$ and lowest in ABAtreated $(0 \%)$ vines (Table 3$)$.

\section{Field Budburst}

On 6 May, budburst in ABA-treated was lower (average $34 \%$ ) than that in control vines $(56 \%)$, indicating a delay of budburst. However, the budburst delay was not observed on May 8 and subsequent dates (Table 4).

\section{Discussion}

\section{Influence of ABA on Yield, Fruit Quality, Dormancy, Freezing Tolerance, and Budburst}

ABA did not impact negatively yield components, fruit composition, or vegetative growth of 'Pinot gris.' These findings are consistent with previous reports on both table grapes (Lurie and others 2009; Peppi and others 2007) and wine grapes including 'Cabernet franc' (Zhang and Dami 2012a), 'Chambourcin' (Zhang and Dami 2012b), and 'Chardonnay' (Dami and others 2015).

The leaf senescence pattern in 'Pinot gris' was similar to that reported in 'Cabernet franc' (Zhang and others 2011;
Zhang and Dami 2012a) and 'Chambourcin' (Zhang and Dami 2012b). These studies reported a reduction of chlorophyll concentration in October, which was the same time as with 'Pinot gris.' The decrease of chlorophyll content is indicative of the slowdown of photosynthesis and initiation of leaf senescence (Evans 1996). The application of exogenous ABA caused early leaf senescence and abscission in 'Pinot gris.' ABA's effects on leaf color change and abscission increased when applied at later phenological stages corresponding to applications on older leaves (134-148 DAB). These findings support previous studies that demonstrated that only older leaves (DAB $\geq 120$ ) were responsive to $\mathrm{ABA}$, by accelerating leaf abscission in treated versus untreated greenhousegrown Vitis 'Cabernet franc' grapevines (Zhang and others 2011). Interestingly, ABA seems to be most effective in reducing chlorophyll content thus hastening senescence at the same time of the year and corresponding to $\mathrm{DAB} \geq 120$ regardless of variety used. It has been reported that leaf senescence is linked with ABA accumulation (Dong and others 2008), by upregulating senescence genes (Park and others 1998).

The delay of budburst in ABA-treated vines suggests that ABA induced deeper dormancy than in untreated vines. These results concur with previous studies with apple (Guak 

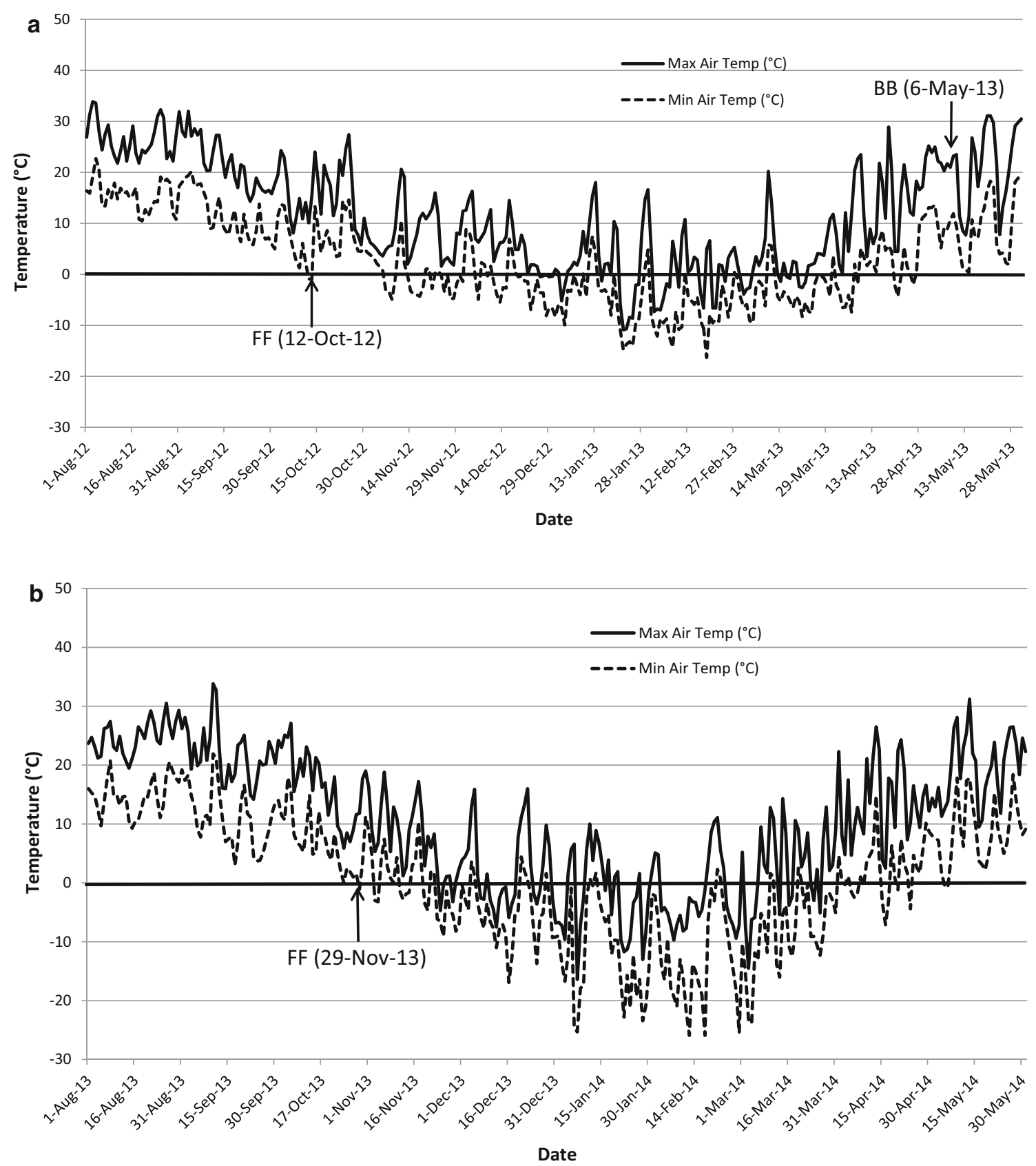

Fig. 5 Daily minimum and maximum temperatures and dates of fall frost (FF) and budburst (BB) recorded at the 'Pinot gris' research vineyard in Kingsville in a study year 1 (2012-2013), and b study year 2 (2013-2014)

and Fuchigami 2001) and grape (Zhang and others 2011; Zhang and Dami 2012a, b). Furthermore, the application timing (véraison and post-véraison) of $\mathrm{ABA}$ effectiveness was similar to that reported with two other grape cultivars, 'Cabernet franc' (Zhang and Dami 2012a) and 'Chambourcin' (Zhang and Dami 2012b). It is known that ABA is a positive regulator of dormancy induction (Kucera and others 2005) and that its concentration increases during dormancy and is highest at the deepest dormancy state (Or and others 2000). Even though ABA concentration was not measured in this study, it is likely that the application of foliar ABA led to an increase in endogenous $\mathrm{ABA}$, which induced maximum dormancy. Moreover, ABA-treated vines reached the same level of dormancy (D50BB 35) 26 days earlier than untreated vines, suggesting that ABA advanced dormancy induction in 'Pinot gris' (Fig. 4b). This response is desirable because it would allow an early cold acclimation and the acquisition of maximum FT.

Our findings that exogenous ABA increased the bud FT of 'Pinot gris' support the results reported in several woody 
plants including grapes (Bertrand and others 1997; Dami and others 2015; Guak and Fuchigami 2001; Zhang and Dami 2012a, b). In 'Pinot gris,' véraison and post-véraison
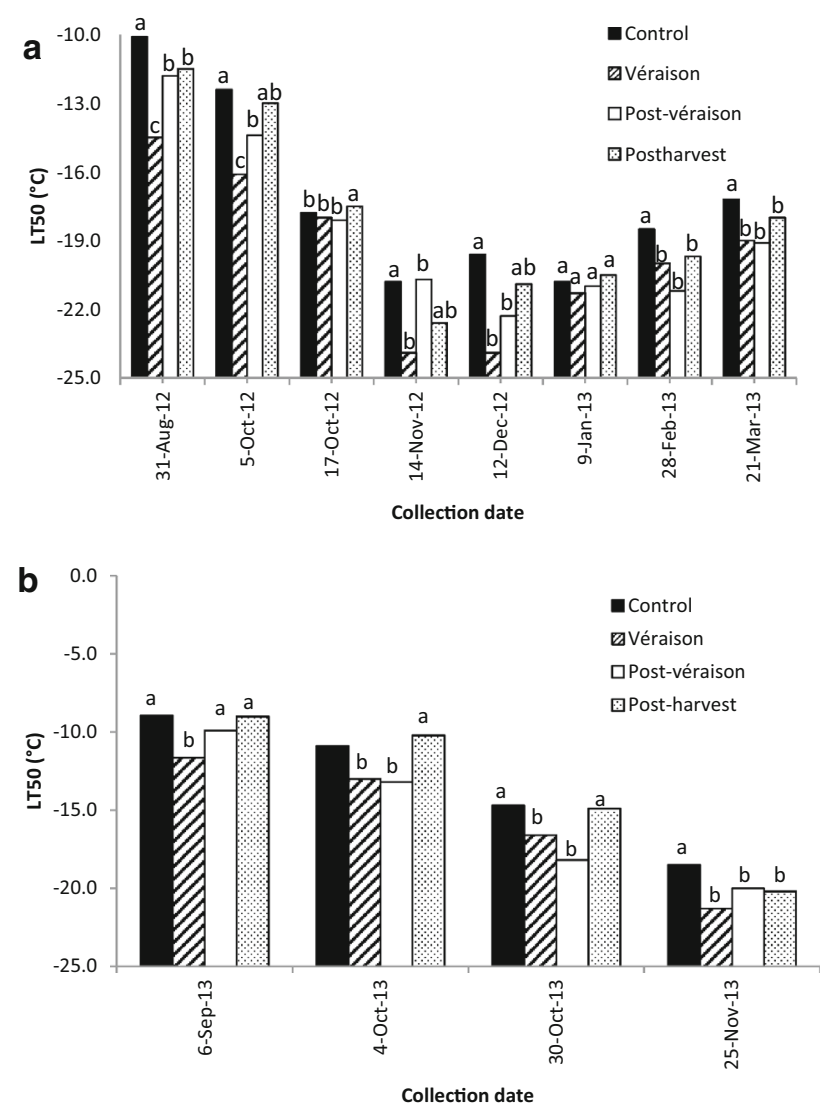

Fig. 6 Effect of ABA on freezing tolerance $\left(\mathrm{LT}_{50}\right)$ in 'Pinot gris' grapevines grown in Kingsville during a 2012-2013 and b 2013-2014 seasons. In 2012, Control, véraison, post-véraison, and postharvest treatments corresponded to ABA application on 16 Aug 2012, 31 Aug 2012, and 28 Sept 2012, respectively. In 2013, Control, véraison, post-véraison, and postharvest treatments corresponded to ABA application on 21 Aug 2013, 17 Sept 2013, and 11 Oct 2013, respectively. Different letters indicate statistical significance at $p \leq 0.05$
ABA treatments had the lowest $\mathrm{LT}_{50} \mathrm{~s}$ and gained an average of $2{ }^{\circ} \mathrm{C}$ in FT during the autumn cold acclimation in both years and during deacclimation in the first year. These findings are similar to those reported in other grape varieties. ABA applied at véraison and post-véraison increased bud FT by up to $4.2{ }^{\circ} \mathrm{C}$ in 'Cabernet franc' between late October and late February (Zhang and Dami 2012a) and $3.5^{\circ} \mathrm{C}$ in 'Chambourcin' between early November and late February (Zhang and Dami 2012b). A multi-location study with 'Chardonnay' confirmed the effectiveness of ABA, and its application timing with FT increases between 1 and $3.3{ }^{\circ} \mathrm{C}$ (Dami and others 2015). The freezing events in 2014 provided an opportunity to evaluate the effectiveness of ABA on field-tested 'Pinot gris' vines. Unfortunately, the damage was total among all types of buds and all treatments. The reasons for the ineffectiveness of ABA can be explained as follows. The lowest FT of 'Pinot gris' or $\mathrm{LT}_{50}$ was $-21.3{ }^{\circ} \mathrm{C}$ prior to the occurrence of $-25.3{ }^{\circ} \mathrm{C}$, which was $4{ }^{\circ} \mathrm{C}$, lower than the bud tissue critical or lethal temperature. Our lab freezing tests consistently showed that ABA increased FT by an average of $2{ }^{\circ} \mathrm{C}$, compared to the control during that time of the year. Therefore, it is possible that ABA provided a $2{ }^{\circ} \mathrm{C}$ of cold protection in treated buds, but an additional

Table 4 Effect of abscisic acid (ABA) on budburst (\%) of 'Pinot gris' grapevines at different observation dates in 2013

\begin{tabular}{llllll}
\hline Treatment $^{\mathrm{a}}$ & 6 May & 8 May & 10 May & 13 May & 16 May \\
\hline Control (no ABA) & $56 \mathrm{a}$ & 88 & 91 & 93 & 94 \\
Véraison & $43 \mathrm{~b}$ & 87 & 92 & 94 & 96 \\
Post-véraison & $30 \mathrm{bc}$ & 80 & 86 & 89 & 91 \\
Postharvest & $28 \mathrm{bc}$ & 81 & 89 & 90 & 92 \\
Significance $^{\mathrm{b}}$ & $*$ & NS & NS & NS & NS \\
\hline
\end{tabular}

a Véraison, post-véraison, postharvest: ABA sprayed at $50 \%$ véraison, 20 and 50 days after $50 \%$ véraison, respectively

b NS, *,**, and *** not significant, significant at $p \leq 0.05,0.01$, and 0.001 , respectively
Table 3 Bud and cane phloem damage of 'Pinot gris' after subfreezing events $\left(-25.3^{\circ} \mathrm{C}\right)$ on 7 Jan 2014

\begin{tabular}{lllll}
\hline Treatment $^{\mathrm{a}}$ & \multicolumn{2}{l}{ Bud damage (\%) } & Cane phloem damage (\%) \\
\cline { 2 - 4 } & Primary bud & Secondary bud & Tertiary bud & \\
\hline Control (no ABA) & 100 & 100 & 100 & $30 \mathrm{a}$ \\
Véraison & 99 & 99 & 97 & $5 \mathrm{~b}$ \\
Post-véraison & 100 & 100 & 100 & $10 \mathrm{~b}$ \\
Postharvest & 100 & 100 & 99 & $0 \mathrm{c}$ \\
Significance $^{\mathrm{b}}$ & $\mathrm{NS}$ & $\mathrm{NS}$ & $\mathrm{NS}$ & $*$ \\
\hline
\end{tabular}

${ }^{a}$ Véraison, post-véraison, postharvest: $\mathrm{ABA}$ sprayed at $50 \%$ véraison, 20 and 50 days after $50 \%$ véraison, respectively

b $\mathrm{NS}, *, * *$, and $* * *$ not significant, significant at $p \leq 0.05,0.01$, and 0.001 , respectively

Samples were collected on 13 Jan 2014 
$4{ }^{\circ} \mathrm{C}$ of protection was needed. Previously, we demonstrated that ABA was effective to protect 'Cabernet franc' from an actual freezing event (Zhang and Dami 2012a). The situation then was different because the minimum air temperatures were warmer $\left(-19\right.$ to $-23{ }^{\circ} \mathrm{C}$ in two locations) in 2011 than in $2014\left(-25.3{ }^{\circ} \mathrm{C}\right)$. Further, the minimum temperatures experienced in 2011 were near the $\mathrm{LT}_{50}$ of 'Cabernet franc.' This was not the case in 2014 where the minimum temperatures were much lower than the $\mathrm{LT}_{50}$. Nevertheless, it was interesting to observe the least injury of the vascular tissue (phloem) in ABA-treated vines. This response could be very significant where $A B A$ could protect the permanent structures such as the cordons and trunks of the vine from freezing injury. However, this needs further investigation.

\section{ABA Effectiveness in Relation to Application Timing}

In this study, the timing of $\mathrm{ABA}$ application was determined using three methods: (1) phenological stages, (2) GDD, and (3) DAB corresponding to the respective phenological stages. Even though ABA was applied at the same phenological stages (that is, véraison, post-véraison, and postharvest) in both years of the study, the corresponding GDDs were different. GDD varied at véraison (943-1138, or $20.7 \%$ variability from year 1 to year 2), post-véraison (1292-1296, or $0.3 \%$ variability), and postharvest (1307-1493, or $14.2 \%$ variability) (Table 1). However, when time of ABA application was expressed as $\mathrm{DAB}$, the variability was not as large as with GDD. DAB at véraison corresponded to 105-107 (or $1.9 \%$ variability from year 1 to year 2), DAB at post-véraison was 120-134 (or $11.7 \%$ variability), and $\mathrm{DAB}$ at postharvest was 148-158 (or $6.7 \%$ variability). Because ABA was most effective between véraison (year 2) and post-véraison (year 1), its application corresponded to DAB between 107 and 134 , respectively. The range of $\mathrm{DAB}$, in which leaves were responsive to exogenous $\mathrm{ABA}$ in 'Pinot gris,' was similar to that reported in 'Chardonnay' (DAB $=95-137$ ) (Dami and others 2015), 'Cabernet franc' $(\mathrm{DAB}=120-140)$ (Zhang and Dami 2012a), and 'Chambourcin' (DAB = 120-130) (Zhang and Dami 2012b). The consistency of the effectiveness of $\mathrm{ABA}$ timing based on $\mathrm{DAB}$ suggests that leaf age influenced the sensitivity to exogenous $\mathrm{ABA}$ and its role on subsequent physiological changes including dormancy induction and acquisition of FT. Because the effectiveness of exogenous ABA is optimum at a narrow time period and DAB showed the least variability, it is critical to define more accurately the timing and the conditions involved during the spray application based on $\mathrm{DAB}$. Therefore, it is suggested that leaf age estimate using
$\mathrm{DAB}$ is a more accurate indicator for timing of $\mathrm{ABA}$ application than the phenological stage of the vine.

In conclusion, exogenous ABA application at concentrations of $400 \mathrm{mg} \mathrm{L}^{-1}$ effectively advanced and induced deeper dormancy and improved the bud FT of 'Pinot gris' without adversely affecting vine size, yield, or fruit quality. The optimum time to spray ABA on 'Pinot gris' was between véraison and 3 weeks post-véraison corresponding to leaf age between $\mathrm{DAB}=107$ and 134. The findings of this study confirmed that ABA might provide an additional tool to protect 'Pinot gris' from freezing damage in cold regions.

Acknowledgments This research was funded by the Department of Horticulture and Crop Science, USDA/NIFA Specialty Crops Research Initiative Award Number 2010-51181-21599 USDA-NIFA, and Ohio Grape Industry Program. We thank Mr. Greg Jones, Ms. Yvonne Woodworth for maintaining the research vineyard at AARS. Ms. Diane Kinney, Mr. Thomas Todaro, Ms. Natalie Fry, Ms. Lisa Robbins, Mr. Steven Park, and Ms. Bailey Miller deserve special thanks for their assistance throughout the duration of this project.

Open Access This article is distributed under the terms of the Creative Commons Attribution 4.0 International License (http://crea tivecommons.org/licenses/by/4.0/), which permits unrestricted use, distribution, and reproduction in any medium, provided you give appropriate credit to the original author(s) and the source, provide a link to the Creative Commons license, and indicate if changes were made.

\section{References}

Agricultural Research Service, U.S. Department of Agriculture (2012) USDA Plant Hardiness Zone Map. http://planthardiness. ars.usda.gov

Bertrand A, Robitaille G, Castonguay Y, Nadeau P, Boutin R (1997) Changes in ABA and gene expression in cold-acclimated sugar maple. Tree Physiol 17:31-37

Bravo LA, Zuniga GE, Alberdi M, Corcuera LJ (1998) The role of ABA in freezing tolerance and cold acclimation in barley. Physiol Plant 103:17-23

Churchill GC, Reaney MJT, Abrams SR, Lawrence VG (1998) Effects of abscisic acid and abscisic acid analogs on the induction of FT of winter rye (Secale cereale L.) seedlings. Plant Growth Regulat 25:35-45

Dallaire S, Houde M, Gagne Y, Saini HS, Boileau S, Chevrier N, Sarhan F (1994) ABA and low-temperature induce freezing tolerance via distinct regulatory pathways in wheat. Plant Cell Physiol 35:1-9

Dami IE, Beam BA (2004) Response of grapevines to soybean oil application. Am J Enol Vitic 55:269-275

Dami IE, Lewis D (2014) 2014 Grape Winter Damage Survey Report. Department of Horticulture and Crop Science Series \#816. The Ohio State University

Dami IE, Ennahli S, Zhang Y (2012) Assessment of winter injury in grape cultivars and pruning strategies following a freezing stress event. Am J Enol Vitic 63:106-111

Dami IE, Kinney D, Li S (2014) Polar vortex and its impact on grapes. Ohio Grape-Wine Electronic Newsletter 10 Jan 2014 (Special Issue):2-6 
Dami IE, Li S, Bowen P, Bogdanoff C, Shellie K, Willwerth J (2015) Foliar applied abscisic acid increases bud freezing tolerance of 'Chardonnay' grapevines during autumn cold acclimation. HortTechnology 23:1-13

Dong H, Niu Y, Li W, Zhang D (2008) Effects of cotton rootstock on endogenous cytokinins and abscisic acid in xylem sap and leaves in relation to leaf senescence. J Exp Bot 59:1295-1304

Eichhorn KW, Lorenz DH (1977) Phenological development stages of the grapevine. Nachrichtenbl Dt Pflanzenschutzd 29:119-120

Evans JR (1996) Developmental constraints on photosynthesis: effects of light and nutrition. In: Photosynthesis and the environment. Kluwer Academic Publishers, The Netherlands, pp 281-304

Guak S, Fuchigami LH (2001) Effects of applied ABA on growth cessation, bud dormancy, cold acclimation, leaf senescence and $\mathrm{N}$ mobilization in apple nursery plants. J Hort Sci Biotechnol 76:459-464

Kucera B, Cohn MA, Leubner-Metzger G (2005) Plant hormone interactions during seed dormancy release and germination. Seed Sci Res 15:281-307

Kumar S, Kaur G, Nayyar H (2008) Exogenous application of abscisic acid improves cold tolerance in chickpea (Cicer arietinum L.). J Agron Crop Sci 194:449-456

Li C, Junttila O, Heino P, Palva TE (2003) Different responses of northern and southern ecotypes of Betula pendula to exogenous ABA application. Tree Physiol 23:481-487

Lurie S, Ovadia R, Nissim-Levi A, Oren-Shamir M, Kaplunov T, Zutahy Y, Weksler H, Lichter A (2009) Abscisic acid improves colour development in 'Crimson Seedless' grapes in the vineyard and on detached berries. J Hort Sci Biotechnol 84:639-644

Mantyla E, Lang V, Palva ET (1995) Role of abscisic-acid in droughtinduced freezing tolerance, cold-acclimation, and accumulation of Lt178 and Rab18 proteins in Arabidopsis-Thaliana. Plant Physiol 107:141-148

Mora-Herrera ME, Lopez-Delgado HA (2007) Freezing tolerance and antioxidant activity in potato microplants induced by abscisic acid treatment. Am J Potato Res 84:467-475
OARDC Weather Station System (2014) Ashtabula Agricultural Research Station. www.oardc.ohiostate.edu/newweather/statio ninfo.asp?id=4. Accessed 24 Oct 2014

Or E, Belausov E, Popilevsky I, Ben Tal Y (2000) Changes in endogenous ABA level in relation to the dormancy cycle in grapevines grown in a hot climate. J Hort Sci Biotechnol 75:190-194

Park JH, Oh SA, Kim YH, Woo HR, Nam HG (1998) Differential expression of senescence-associated mRNAs during leaf senescence induced by different senescence-inducing factors in Arabidopsis. Plant Mol Biol 37:445-454

Peppi MC, Fidelibus MW, Dokoozlian NK (2007) Application timing and concentration of abscisic acid affect the quality of 'Redglobe' grapes. J Hort Sci Biotechnol 82:304-310

Poling EB (2008) Spring cold injury to winegrapes and protection strategies and methods. HortScience 43:1652-1662

Ravaz L (1903) Sur la brunissure de la vigne. Les Comptes Rendus de l'Académie des Sciences 136:1276-1278

Smart R, Robinson M (1991) Sunlight into wine: a handbook for winegrape canopy management. Winetitles, Adelaide

Wake C, Fennell A (2000) Morphological, physiological and dormancy responses of three Vitis genotypes to short photoperiod. Physiol Plant 109:203-210

Wolf TK, Pool RM (1987) Factors affecting exotherm detection in the differential thermal analysis of grapevine dormant buds. J Am Soc Hort Sci 112:520-525

Zabadal T, Dami IE, Goffinet M, Martinson T, Chien M (2007) Winter injury to grapevine and methods of protection. Michigan State University Extension, East Lansing

Zhang Y, Dami IE (2012a) Foliar application of abscisic acid increases freezing tolerance of field-grown Vitis vinifera 'Cabernet franc' grapevines. Am J Enol Viticult 63:377-384

Zhang Y, Dami IE (2012b) Improving freezing tolerance of 'Chambourcin' grapevines with exogenous abscisic acid. HortScience 47:1750-1757

Zhang Y, Mechlin T, Dami IE (2011) Foliar application of abscisic acid induces dormancy responses in greenhouse-grown grapevines. HortScience 46:1271-1277 